\title{
Relationship between protein intake (PDI) and net portal appearance rate of amino acids in lactating goats
}

\author{
C Champredon, S Tesseraud, E Debras, G Bayle, J Lefaivre, J Grizard
}

\begin{abstract}
INRA, Laboratoire d'Étude du Métabolisme Azoté,Theix, 63122 Saint-Genès-Champanelle, France
\end{abstract}
Three lactating goats (body weight $39.4-45.5 \mathrm{~kg}$; milk yield $2.0-3.6 \mathrm{~kg} / \mathrm{d}$ ) were used during midlactation. They were fed a concentrate containing mainly maize (Champredon et al, 1990) and a mixture of meadow and lucerne chopped hays (2:1) both given at variable levels. Dry matter intake varied from 1430 and $2630 \mathrm{~g} / \mathrm{d}$ and the PDI (digestible protein in the intestine; Jarrige, 1989) intake from 130 to $280 \mathrm{~g} / \mathrm{d}$. The goats were surgically fitted with catheters in the carotid artery, the portal vein and a mesenteric vein. Portal plasma flow was measured by continuous infusion of para-aminohippuric acid via the mesenteric catheter. The amino-acid appearance rate from the portal-drained viscera was obtained from portal plasma flow, and the differences between venous and carotid plasma concentrations. Three to 4 measurements (corresponding to different levels of dietary intake) were performed on each goat on different days.

The portal plasma flow of the lactating goats used in the present study ranged from 58 to $69 \mathrm{ml} / \mathrm{min} / \mathrm{kg}$ body weight. The coefficients of the linear regression relating the net portal appearance rate of amino acids (NPA in $\mathrm{g} / \mathrm{d}$ ) to the PDI- intake $(g / d)$ are given in table I. All regression coefficients (b) were significant $(P<0.01)$. Intercepts (a) were significantly different from the origin $(P<0.05)$ except for threonine $(P=0.29)$.

From these results, it appears that there is a good linear relationship between protein intake and the net appearance rate of essential amino acids in the portal vein. This is true at least for the protein intake interval of our experiment. The negative values of the intercept may indicate that there is a marked utilization of amino acids by the gastrointestinal tract. It has been shown that protein synthesis by the digestive tract of the goat increases during lactation by comparison with dry animals (Champredon et al, 1990). Consequently, the measurement of the amino-acid appearance rate in the portal vein may not be representative of dietary amino-acid supply to the whole body.

Champredon C, Debras E, Patureau, Mirand P. Arnal M (1990) J Nutr 120, 1006-1015

Jarrige R (1989) Ruminant Nutrition - Recommended Allowances and Feed Tables, John Libbey, London

Table I. Parameters of the linear regression, NPA $(g / d)=a+b \bullet$ PDI $(g / d)$.

\begin{tabular}{lrrrrr} 
& NPA & a & b & $r s d$ & $r$ \\
\hline Valine & & & & & \\
Isoleucine & $7.45 \pm 6.05$ & $-13.4 \pm 2.6$ & $0.11 \pm 0.01$ & 2.09 & 0.95 \\
Leucine & $8.19 \pm 4.74$ & $-7.6 \pm 2.5$ & $0.08 \pm 0.01$ & 2.02 & 0.92 \\
Tyrosine & $13.29 \pm 6.49$ & $-9.6 \pm 2.2$ & $0.12 \pm 0.01$ & 1.77 & 0.97 \\
Phenylalanine & $7.85 \pm 5.19$ & $-8.2 \pm 3.0$ & $0.09 \pm 0.02$ & 2.49 & 0.89 \\
Threonine & $8.77 \pm 5.49$ & $-10.4 \pm 2.1$ & $0.10 \pm 0.01$ & 1.71 & 0.96 \\
& $6.79 \pm 2.76$ & $-2.0 \pm 1.7$ & $0.05 \pm 0.01$ & 1.40 & 0.88 \\
\hline
\end{tabular}

Mean values with their standard deviations for 10 determinations. 